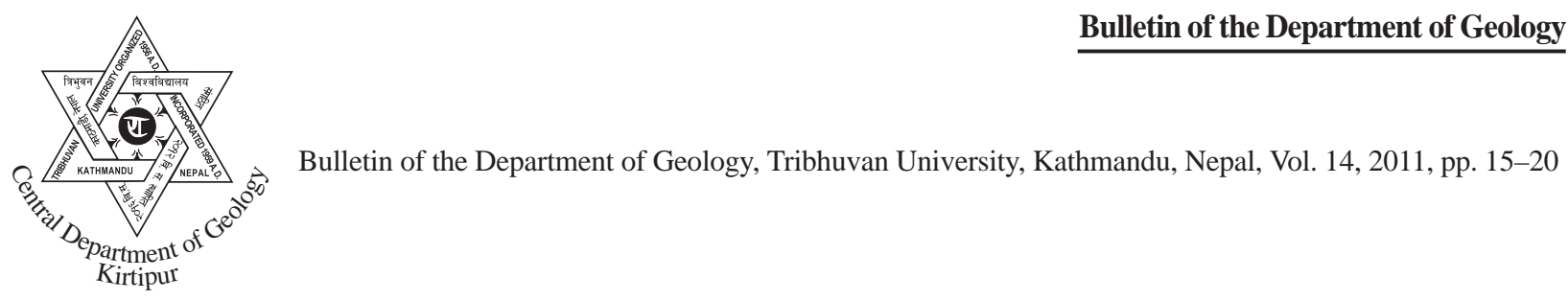

\title{
Petrographic analysis of carbonate rocks for alkali-aggregate reactivity
}

\author{
*Naresh Kazi Tamrakar and Lalu Prasad Paudel \\ Central Department of Geology, Tribhuvan University, Kirtipur, Kathmandu, Nepal
}

\begin{abstract}
Quality of aggregate is of extreme concern when it is to be used for infrastructures. Besides, many physical and mechanical properties of the aggregate, presence or absence of deleterious constituents and alkali-silica reactivity are especially important when aggregates are to be used in concrete structures. High potential of alkali-silica reactivity or alkali-carbonate reactivity and presence of deleterious constituents may impair the infrastructures.

A ledge rock sample from the heap to be taken for crushing was petrographically analysed for alkali-silica reactivity. In overall, two rock clans (dolosparstone and dolomicrosparstone) with three sub clans (rock type X, Y and Z) from the sample 2 are identified. Rock type X (dolosparstone) constitutes $82.94 \%$ of the whole sample, and shows notable amount of quartz and calcite veins, and carbonaceous material and hematite on the mosaic of dolospars. Rock types Y (dolosparstone) and Z (dolomicrosparstone) contain trace amount of microquartz, mega quartz $(>15 \mu \mathrm{m})$ and carbonaceous opaques. The rock type $\mathrm{Z}$ is dominantly composed of dolomicrospars. Major portions of all the rock types are characterised by mosaics of dolomite in association with variable amounts of muscovite, quartz, and calcite. Calcite often replaces the mosaics of dolomite and bands of quartz, forming a vein networks in rock types $\mathrm{X}$ and $\mathrm{Y}$. Silica is represented by a low-temperature mega quartz either in ground or in veins, a trace amount of microquartz in rock types $\mathrm{Y}$ and $\mathrm{Z}$. There is no other reactive silica components, thus showing a low potential to alkali-silica reactivity. However, the sample shows potential of alkali-carbonate reactivity as significant proportion of rock type having dolomicrospars are found.
\end{abstract}

\section{INTRODUCTION}

Quality of aggregate is of great concern to infrastructural projects which utilise aggregates for various purposes, e.g., building, dams, bridges, pavements, etc. The durability of structures partly rely on the quality of construction material used in the structures. The physical properties and proportion of deleterious materials which bear potential reactivity with the cement are crucial in any projects which uses cement to bind the aggregate for making concrete structures. Physical properties are greatly influenced by composition and texture of aggregates, and proportion of deleterious constituents are influenced by composition of constituent rock types in aggregates and degree of weathering of the constituents.

\footnotetext{
*Corresponding author:

E-mail address: ntamrakar@hotmail.com
}

Petrographic examination of aggregates is the most crucial part of characterising aggregates during the study of aggregates. In many instances, petrographic results are decisive in accepting or rejecting the aggregates, and are helpful in deciding whether the aggregate samples are to be further analysed for chemical and physical tests. Therefore, requirement of further chemical and physical tests is governed by petrographic results because the latter supplements other expensive and time consuming tests.

There are little number of earlier studies on petrography of rocks for aggregates in the Nepalese context (Maharjan and Tamrakar, 2004; Maharjan and Tamrakar, 2008; Khanal and Tamrakar, 2009). Few of these studies carried out physical and mechanical tests and indicated suitability of rocks or gravels for concrete or road aggregates. The present study is mainly targeted to petrographic examination for alkali-silica reactivity of a rock sample for concrete aggregates. 


\section{METHODOLOGY}

The main sample analysed was obtained from a crusher plant of the Bhagwati Stone Industries (P) Ltd., Banepa, Kavre District. The Bhagwati Stone Industries Pvt. Ltd. brings stones from the quarry sites away from Banepa. The sample was taken to laboratory for petrographic analysis.

Rock fragments were examined and were categorised based on their physical characteristics and rock types. Each of the categories of rock types was thin-sectioned and examined under petrographic microscope considering ASTM Designation C295-03 (ASTM International, 2003). About 200 counts per sub-sample were made for determining composition. The texture indicating alkali-aggregate reactivity was also examined. To assist for determination of clay minerals and deleterious silica components, X-ray diffraction analyses were made for selected portion of the fragments of rocks. Mainly air dried samples were used in XRD machine (Bruker's D8 advance diffractometer, computer controlled). The scan ranges for bulk mineralogy were $2-402 \theta$ at a speed $1 \%$ min, $20-222 \theta$ at a speed of $0.25 \% \mathrm{~m}$ for detection of silica, and 6-14 $2 \theta$ at a speed of $0.25 \% \mathrm{~m}$ for detection of clay minerals.

\section{RESULTS OF PETROGRAPHIC ANALYSES}

\section{Megascopic features}

The results of megascopic examination of rock fragments are given in Table 1. Rock fragments are flaky, flaky and elongate and are angular to very angular. They are often fine-grained, massive to poorly

Table 1: Description of physical characteristics of a ledge rock sample

\begin{tabular}{ll}
\hline Physical characteristics & Description \\
\hline 1. Particle shape & Flaky, flaky and elongate; angular to very angular \\
\hline 2. Surface texture & Rough, fractured surfaces \\
\hline 3. Nominal size & Almost between 70 and $230 \mathrm{~mm}$ \\
\hline 4. Internal structure & $\begin{array}{l}\text { Massive to weakly laminated, with partings } \\
\text { and vein networks }\end{array}$ \\
\hline 5. Colour & Dark grey, light grey, with yellowish coating \\
\hline 6. Coatings & $\begin{array}{l}\text { Calc. dust dominantly on fractured surface, } \\
\text { and very thin on freshly broken surface }\end{array}$ \\
\hline 7. Heterogeneity & Low \\
\hline
\end{tabular}

Table 2: Composition of a ledge rock sample

\begin{tabular}{clc}
\hline Category & \multicolumn{1}{c}{ Description } & Weight \% \\
\hline $\mathrm{X}$ & $\begin{array}{l}\text { Finely crystalline, dolo-sparstone } \\
\text { with network of thin veins }\end{array}$ & 82.94 \\
\hline $\mathrm{Y}$ & $\begin{array}{l}\text { Finely crystalline, dolo-sparstone } \\
\text { with mica partings }\end{array}$ & 8.22 \\
\hline $\mathrm{Z}$ & $\begin{array}{l}\text { Very finely crystalline, dolo- } \\
\text { microsparstone }\end{array}$ & 8.84 \\
\hline \multicolumn{2}{c}{ Total } & 100 \\
\hline
\end{tabular}

laminated, and dark grey to grey (Table 1). The major portion of rock fragments is carbonate, and is accompanied with micaceous partings and clayey mantle layer. Veins form subparallel to oblique network in these subsamples.

The sample consists of three categories (Table 2). rock type $\mathrm{X}$ and $\mathrm{Y}$ are finely crystalline dolo-sparstones. $\mathrm{X}$ is with network of thin veins whereas $\mathrm{Y}$ is with mica partings. Rock type $\mathrm{Z}$ is very finely crystalline dolomicrosparstone. Rock type $\mathrm{X}$ predominates the bulk of the sample (Table 2).

\section{Composition and texture of individual rock types}

Each of the three rock types was further examined under the petrological microscope and their selected portions were analysed further in XRD to aid identification of deleterious minerals otherwise undetectable under a petrological microscope. The results of 200 point counts in each type of rock are shown in Table 3.

\section{Rock type X}

Rock type $\mathrm{X}$ is a dolo-sparstone with vein networks. The rock type $\mathrm{X}$ is characterised by a mosaic of dolospars $(30-150 \mu \mathrm{m})$, muscovite, calcite $(150 \mathrm{~mm})$, and quartz $(30-50 \mu \mathrm{m})$. Both dolospar and calcite spar tend to align along the plane defined by muscovite.

Table 3: Percent constituents of individual rock type

\begin{tabular}{lccc}
\hline $\begin{array}{l}\text { Wt\% of individual Rock } \\
\text { type }\end{array}$ & $\mathrm{X}$ & $\mathrm{Y}$ & $\mathrm{Z}$ \\
& 82.94 & 8.22 & 8.84 \\
\hline Dolomite & 70 & 75 & 84 \\
Calcite & 14 & 6 & 3 \\
Quartz, mega & 7 & 4 & 1 \\
Quartz, micro & - & 1 & 2 \\
Muscovite & 4 & 10 & 8 \\
Fe-oxide & 1 & - & - \\
Carbonaceous opaque & 4 & 4 & 2 \\
\hline & 100 & 100 & 100 \\
\hline
\end{tabular}




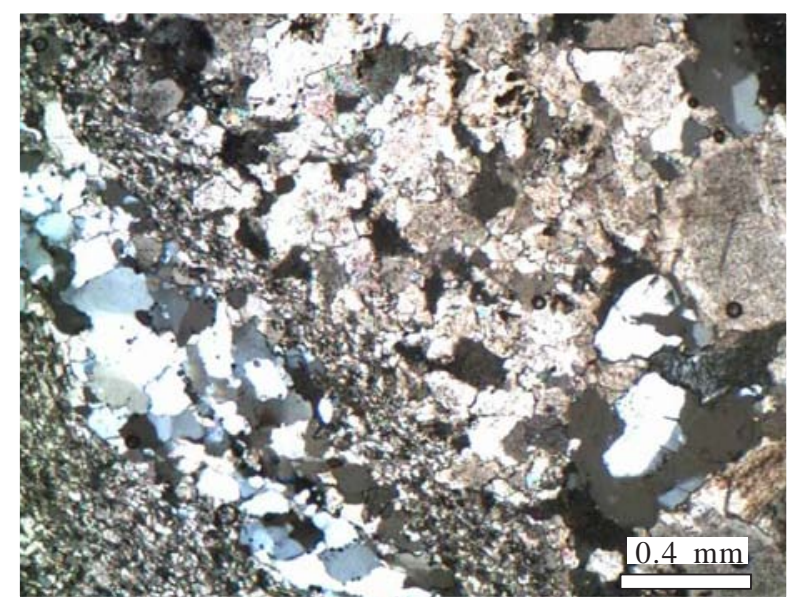

Fig. 1 Photomicrograph of finely crystalline, dolo-sparstone (subsample X, section 1) showing a distinct quartz vein, dolospar bands, and a calcitic vein at the upper right portion, replacing earlier quartz.

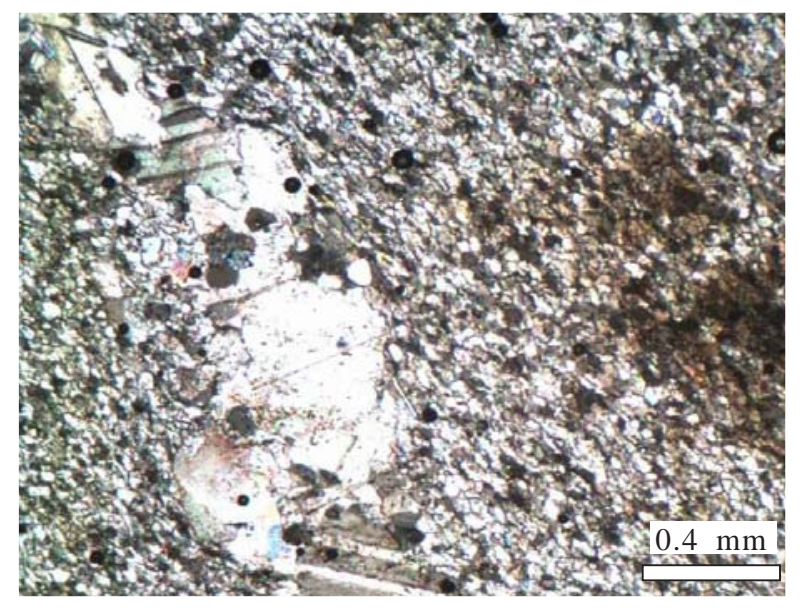

Fig. 2 Photomicrograph of finely crystalline, dolo-sparstone (subsample X, section 2) showing a mosaic of dolostone with ferrugineous patches in the upper right, and a distinct calcite vein in the lower left portion.

Quartz veins contain 100-1000 $\mu \mathrm{m}$ sized quartz which are undulose, angular and sutured (Fig. 1). Veins of 2-3 mm thickness of made up of calcite spars (40-1600 $\mu \mathrm{m})$ also extend. Dolospars are frequently coated with carbonaceous opaque. Calcite spars are found to replace quartz (Fig. 1) showing relict and are usually of 30-80 $\mu \mathrm{m}$. Pressure shadow at the margin of coarse calcitic vein shows deformed and elongate crystals of calcite and micas. Hematite is spotty and as coating over calcite. They might have been generated from transformation of dolomite to calcite through release of iron oxides (Buendia et al., 2008).

In other sections, a mosaic of dolospars are associated with preferredly arranged muscovite. The

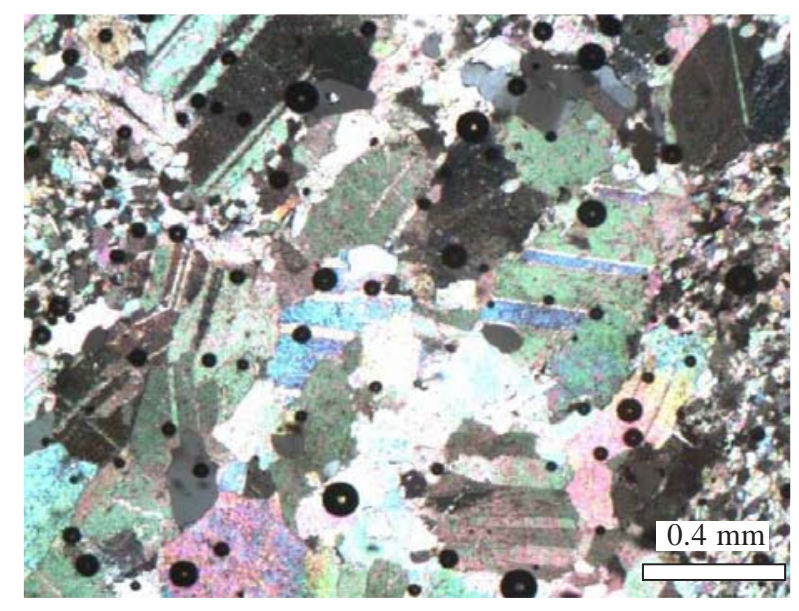

Fig. 3 Photomicrograph of finely crystalline, dolo-sparstone (subsample X, section 4) showing a mosaic of dolospar and muscovite, and a thick vein of giant calcite spars. These spars show multiple twinning.

mosaic often bears patchy iron oxides. Bands of sparry calcite (Fig. 2) and quartz extend along the plane of a major trend of mica alignment. In some other section (Fig. 3), the host bands of dolospar (80-100 $\mu \mathrm{m})$ mosaic in association with elongate and preferredly arranged muscovite contain bands ( $4 \mathrm{~mm}, 0.8 \mathrm{~mm}, 2.8$ $\mathrm{mm}$, etc.) of calcite spar (300-800 $\mu \mathrm{m}$ sized) which includes isolated and rounded relict quartz of 80-120 and 40-100 $\mu \mathrm{m}$ sizes .

\section{Rock type $\mathrm{Y}$}

Rock type $\mathrm{Y}$ is a finely crystalline, dolo-sparstone with mica partings. Dolomite, muscovite, calcite and quartz make up a mosaic in which dolospars and micas tend to elongate along a plane (Fig. 4 ). Spars of calcites $(50-80 \mu \mathrm{m})$ and dolomites $(20-30 \mu \mathrm{m})$ occur as pore filling and replacing constituents showing reaction rims developed around silicate grains. Patchy appearance of calcitic spars is characteristics. Quartz grains are usually 30-60 $\mu \mathrm{m}$ in size. They are angular, equant and with sutured to long contacts (Fig. 4). They are slightly undulose and without intense fracturing. Sericite occurs as tiny flakes and occurs between other silicate grains. Small fragments of tourmaline and pyrite crystals scatter in the rock.

\section{Rock type Z}

Rock type $\mathrm{Z}$ is a very finely crystalline dolomicrosparstone. It consists of basically a mosaic of dolomicrospars (4-32 $\mu \mathrm{m}$ in size) along with muscovite and quartz grains (Fig. 5 and 6). Dolomicrospars are elongate and tend to lie in a plane defined by the arrangement of muscovite. Few thin quartz bands occur 


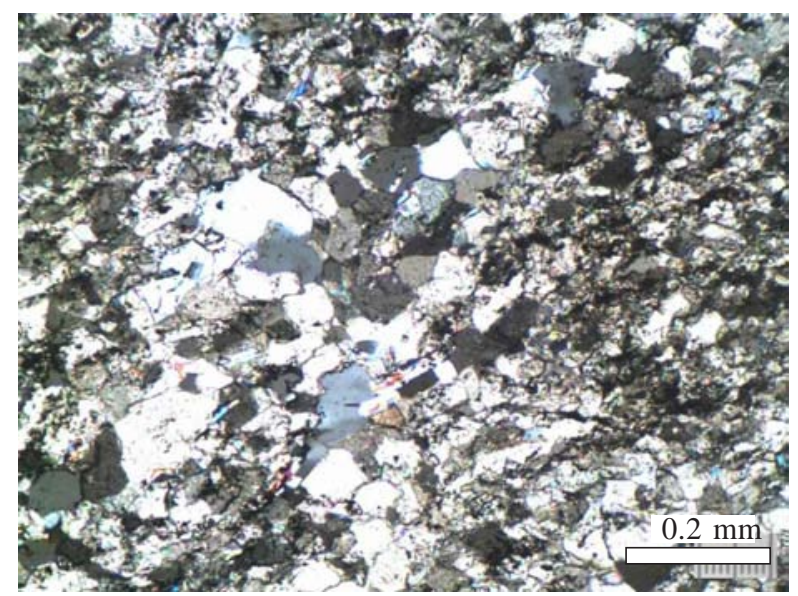

Fig. 4 Photomicrograph of finely crystalline, argillaceous dolosparstone (subsample Y) showing dolospar mosaic and distribution of patches of quartz aggregate along with calcitic replacement.

containing megaquartz (Fig. 6). These bands are frequently obliterated by the attack of dolomites.

\section{WEIGHTED COMPOSITION OF LEDGE ROCKS}

Table 4 lists the composition of individual rock type in terms of weighted percentage. Three rock types as $\mathrm{X}, \mathrm{Y}$ and $\mathrm{Z}$ are compositionally similar but differ in terms of proportion of constituents and crystal size. Rock type X occupies major portion (82.94\%) of the sample, whereas $\mathrm{Y}$ and $\mathrm{Z}$ constitute lower proportion. Rock type $\mathrm{X}$ constitutes notable amount of veins of quartz and calcite, and also opaque of carbonaceous material and hematite. Rock types $\mathrm{Y}$ and $\mathrm{Z}$ contain trace amount of microquartz in the mosaics of dolomite, and trace amounts of mega quartz (> $15 \mu \mathrm{m}$ ) and carbonaceous opaques.

\section{ALKALI-SILICA REACTIVE POTENTIAL}

Alkali-silica reaction in aggregate occurs through attack of alkali solution to reactive silica and formation of a silica gel that swells as it draws water from surrounding and continues to increase in volume. In absorbing water, gel can induce pressure expansion of aggregate, thus causing the aggregate and surrounding cement of concrete to be cracked. The reaction rate depends on proportion of reactive aggregate in concrete, alkali content of cement, temperature and availability of water (Gillott, 1975). Some harmful and alkali-silica reactive constituents

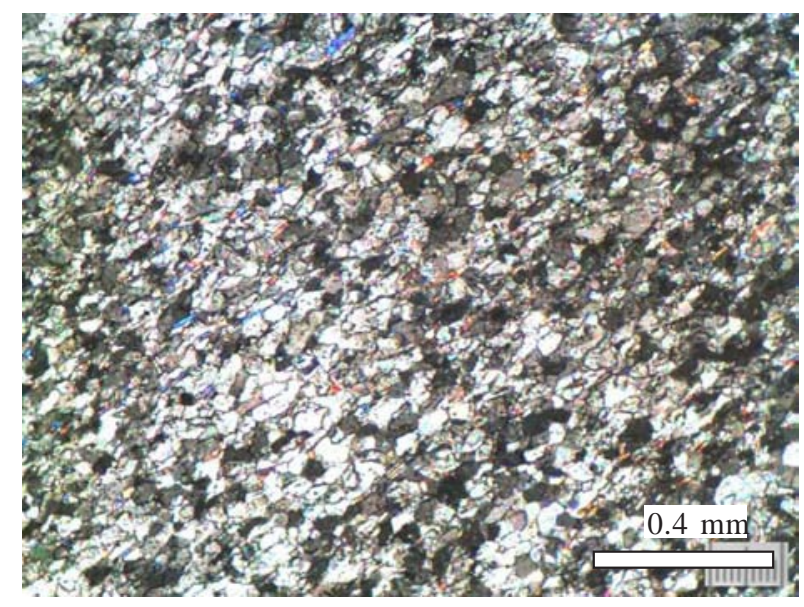

Fig. 5 Photomicrograph of very finely crystalline, argillaceous dolo-microsparstone (subsample Z, section 2) exhibiting a mosaic of very finely crystalline dolomicrospars and small muscovites. Onto this mossaic, few micro quartz grains are scattered.

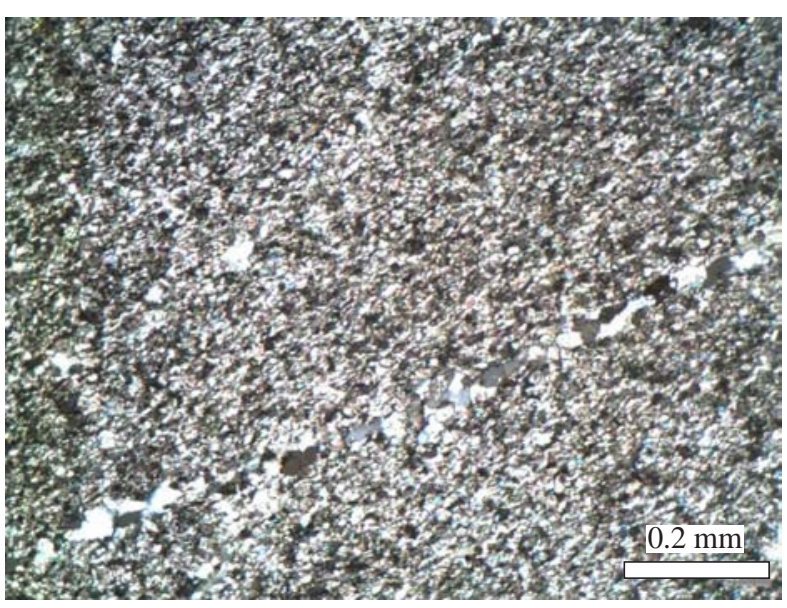

Fig. 6 Photomicrograph of very finely crystalline dolomicrosparstone (subsample Z, section 2) showing a mosaic of dolomicrospar in association with small muscovite, which tend to arrange preferredly. On to the mosaic, few quartz grains are scattered. Most of the bright grains showing high interference colour are dolomites.

are chalcedony, chert, microquartz, opal, high-T silica; cristoballite and tridymite, etc.

Rock type X constitutes major portion $(82.94 \%)$ of the samples and contains extensive vein networks. To determine whether these veins contain microcrystalline quartz as chert and chalcedony, thinsections from different rock fragment pieces were analysed. Quartz grains which occur in main rock domains and veins of all the four sections studied are found to be mega quartz. The latter exhibits low deformation. There is no other reactive silica component 
Petrographic analysis of carbonate rocks for alkali-aggregate reactivity

Table 4: Weighted percentage of constituents of individual rock types

\begin{tabular}{lcllc}
\hline & $\mathrm{X}$ & $\mathrm{Y}$ & $\mathrm{Z}$ & $\begin{array}{c}\text { Weighted } \\
\text { composition }\end{array}$ \\
\hline Dolomite & 58.1 & 6.2 & 7.4 & 71.6 \\
Calcite & 11.6 & 0.5 & 0.3 (trace) & 12.4 \\
Quartz, mega & 5.8 & 0.3 (trace) & 0.1 (trace) & 6.2 \\
Quartz, micro & - & 0.1 (trace) & 0.2 (trace) & 0.3 (trace) \\
Muscovite & 3.3 & 0.8 & 0.7 & 4.8 \\
Fe-oxide & 0.8 & - & - & 0.8 \\
Carbonaceous opaque & 3.3 & 0.3 (trace) & 0.2 (trace) & 3.8 \\
\hline & 83 & 8.22 & 8.84 & 100.0 \\
\hline
\end{tabular}
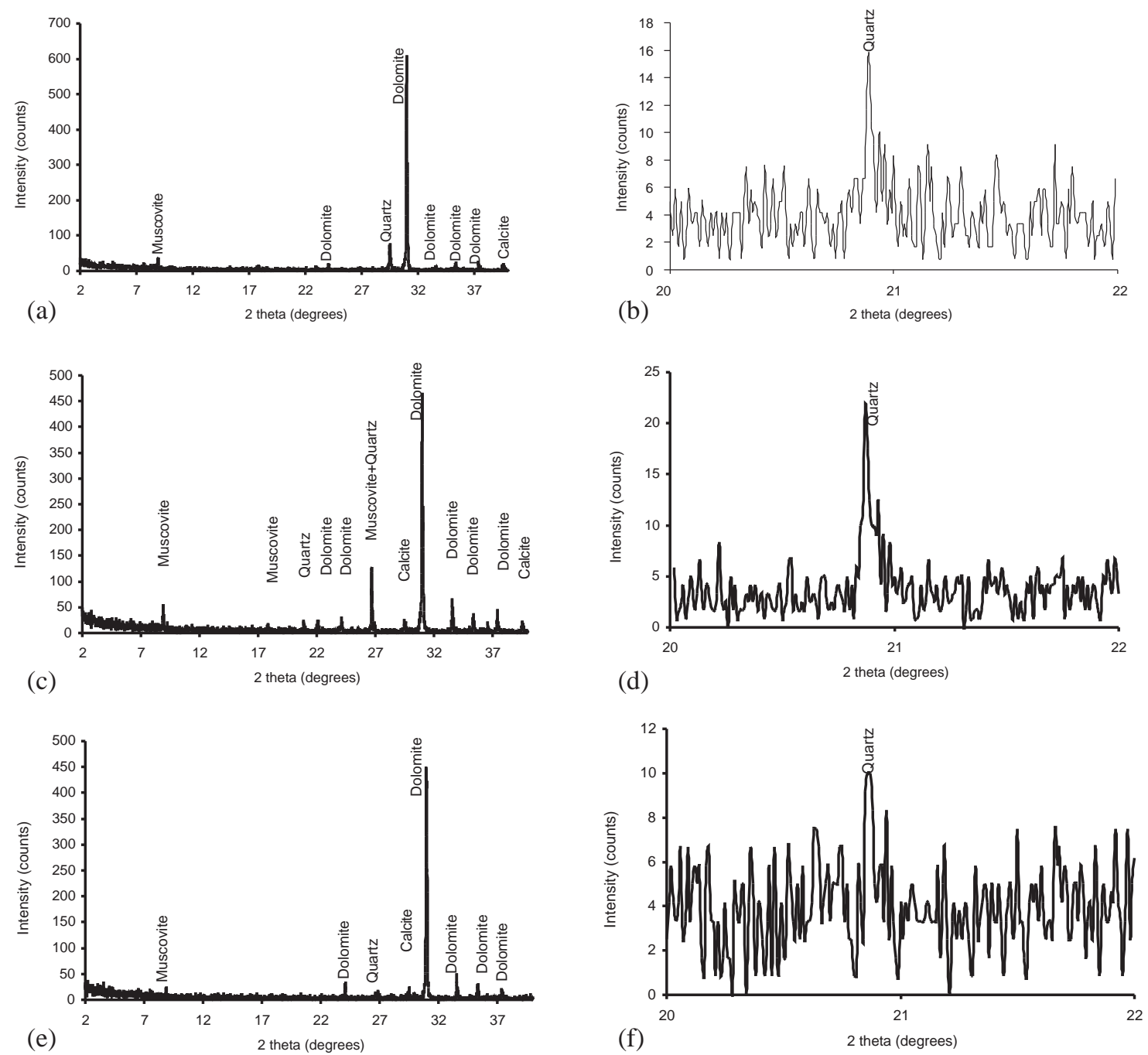

Fig.7 Diffractograms of rock samples: (a) Bulk composition of sample X, (b) Silica scan of sample X, (c) Bulk composition of sample Y, (d) Silica scan of sample Y, (e) Bulk composition of sample Z, and (f) Silica scan of sample Z.

obtained from XRD analysis (Fig. 7). All the quartz grains are entirely low-T quartz type. Therefore, the vein networks which were suspected to contain chert or chalcedonic quartz, are devoid of these as well as other deleterious silica constituents.

Silica component in rock type $\mathrm{Y}$ is represented by low-quartz grains. These quartz grains are mega quartz 
crystals and are devoid of intense deformation fabric. They contain no intense fractures. The rock also lacks veins having chert. Therefore, there is no reactive silica in the rock.

Similarly, the rock type $\mathrm{Z}$ contains dolomite in greater proportion compared to other constituents, such as calcite and both mega and micro quartz, which are found in trace amount. Therefore contribution of these constituents to the whole rock sample is negligible, and thus, alkali-silica reactivity is negligible.

Though these samples show low potential to alkalisilica reactivity, they may be potential to alkalicarbonate reaction. Alkali carbonate reaction enhances dedolomitization process during which change of dolomite to calcite takes place with dilation (Buendia et al., 2008). Dedolomitization process is associated with expansive alkali carbonate reaction (Hadley, 1961). Dedolomitization is potential in small size of discrete dolomite crystals (Ozol, 1994). Aggregates have potential for alkali carbonate reaction yielding expansion if dolomite crystals are fine, clay content range from $5-25 \%$, and if the crystals are interlocked and crystalline so that the dilation during dedolomitization and dilation become cause of straining (Swenson, 1967; Ozol, 1994). Such constituents are found in dominant proportion in the rock type $\mathrm{Z}$, showing greater potential to alkali carbonate reactivity.

\section{CONCLUSIONS}

In overall, three rock types from the ledge rock sample have been identified. Fundamentally, these rock types belong to dolo-sparstone and dolomicrosparstone, and are compositionally similar but differ in terms of proportion of constituents and crystal size. Rock type X constitutes $82.94 \%$ of the whole sample, and show notable amount of veins of quartz and calcite, and also opaque of carbonaceous material and hematite. Rock types $\mathrm{Y}$ and $\mathrm{Z}$ contain trace amount of microquartz in the mosaics of dolomite, and trace amounts of mega quartz and carbonaceous opaques.

Major portions of all the rock types are characterized by mosaics of dolomite in association with variable amounts of muscovite, quartz, and calcite. Dolospars in $\mathrm{X}$ and $\mathrm{Y}$ and dolomicrospars in rock type $\mathrm{Z}$ tend to be slightly elongate along the direction of preferred planes defined by alignment of muscovites. Notable calcite replacement obliterates the mosaics of dolomite and the bands of quartz aggregates. Calcite spars produce vein networks in rock types $\mathrm{X}$ and $\mathrm{Y}$.
All the quartz grains either in ground or in veins in rocks are identified as low-temperature quartz. Based on size, the major portion of the rock sample contains mega quartz. Though $\mathrm{Y}$ and $\mathrm{Z}$ type rocks contain microquartz grains, the latter are trace in amount. There is no other reactive silica components, nor such components are found in veins. Therefore dolosparstones and dolo-microsparstones have low potential to alkali-silica reactivity. However, dolomicrosparstones, which approach $8.84 \%$ in bulk of the sample, indicate interlocked fabric with very fine crystals of dolomite. These features are potential to alkali-carbonate reaction. If the rock type $\mathrm{Z}$ can be avoided, the quality of the aggregate will improve.

\section{REFERENCES}

ASTM International, 2003. Standard guide for petrographic examination of aggregates for concrete.C295-03. pp. 1-8. (www.astm.org).

Buendia, A.L.M, Climent, V., Urquiola, M.M., and Bastida, J., 2008. Influence of dolomite stability on alkali carbonate reaction. (Eds) Broekman and Wigum, Proc. 13th ICAAR, Trondiem, 1359p.

Gillott, J.E., 1975. Alkali-aggregate reactions in concrete. Eng. Geol., v. 9, pp. 303-394.

Hadley, D.W., 1961. Alkali reactivity of carbonate rocksexpansion and dedolomitization. Research Department Bulletin, RX139, Portland Cement Association, http://www.portcement.org/pdf_files/RX139.pdf.

Khanal, A. and Tamrakar, N.K., 2009. Evaluation of quality of crushed-limestone and -siltstone for road aggregate. Bull. Dept. Geol., Tribhuvan University, Nepal, v. 12, pp. 29-42.

Maharjan, D.K. and Tamrakar, N.K., 2004. Quality of siltstones for concrete aggregate from Nallu Khola area, Kathmandu valley. Proceedings of Forth Nepal Geological Congress, Jour. Nepal Geol. Soc., v. 30 (Special Issue), pp. 167-176.

Maharjan, S. and Tamrakar, N.K., 2007. Evaluation of gravel for concrete and road aggregates, Rapti River, Central Nepal Sub-Himalaya. Bull. Dept. Geol., Tribhuvan University, Nepal, v. 10, pp. 99-106.

Ozol, M.A., 1994. Alkali-carbonate rock reaction, significance of tests and properties of conrete and concrete making materials, ASTM STP 169C, edited by Klieger, Paul and Lamond, Joseph F., American Society for Testing and Materials, Philadelphia, pp. 372-387.

Swenson, E.G. and Gillott, J.E., 1967. Alkali reactivity of dolomitic limestone aggregate. Magazine of concrete research, v. 19, no. 59, Cement and Concrete Association, London, pp. 95-104. 